\title{
Adaptation Trail of Improved Legume Cowpea, (Vigenia Angulucata) at Haro Sabu, Kelem Wollega Zone, Oromia, Ethiopia
}

\author{
Negasu Gamachu $^{1 *}$, Gizahagn Mengistu' ${ }^{1}$, Gizahu Wekgari ${ }^{1}$ \\ ${ }^{1}$ Oromia Agricultural Research Institute (IQQO), Haro Sabu Agricultural Research Centre, \\ Haro Sabu, Kelem Wollega Zone, Oromia regional state, Ethiopia \\ *negasugamachu@gmail.com
}

\begin{abstract}
The study was conducted with the objective to identify better adaptable, disease resistant, herbage and grain yield of cowpea accessions under Haro sabu ARC on station. The five cowpea accession adaptation tested included accession Cowpea12688, Cowpea17216, CowpeaIt82d889, Cowpea82d889 and Cowpea Ivu11421. Herbage dry matter and grain yield, and other agronomic data (50\% flowering, disease incidence,) were measured to distinguish better adaptable accession. From the analysis result, there was statistical significance difference $(p<0.05)$ observed between treatments. From adapted cowpea accessions, Cowpealt82d889 accession was better adaptable, coverage, resist disease and produced high herbage dry matter yield 10.56 ton/ha compared to the rest accessions Cowpea82d889 were followed. It is concluded that CowpeaIt82d889, Cowp82d889, were better performance accessions which are suitable for use as animal feeds.
\end{abstract}

Keywords: Herbage dry matter yield; grain yield; Cowpea.

\section{INTRODUCTION}

In most tropical countries, in adequate supply of feed is the bottleneck to livestock production. Basically, this is due to the dependence of livestock on naturally available feed resources and little development of forage crops for feeding to animals. Improved pasture and forage, natural pasture, crop residue and agro industrial by products and other by-products like food and vegetable refusal are major livestock feed resources in Ethiopia. Feed shortage both in terms of quantity and quality is a major problem hindering the development of livestock industry in Ethiopia. The shortage of improved forage, poor quality of existing feeds and fluctuating feed supply are major constraints to increasing livestock productivity (Sere et. al., 2008).

Cowpea (Vigenia angulucata) is an annual legume grown throughout the semi-arid tropics, where it is valued and potential to produce high levels of fodder for livestock in addition to grain for people. Its dual purpose character, weeds suppressing ability, positive impact on soil properties, drought tolerance and being a warm weather crop makes cowpea an attractive and promising forage species in a typical tropical lowland climate. It is usually better adapted to drought, high temperatures and other biotic stresses than other crop plant species (Ehlers and Hall, 1997; Kuykendall et. al., 2000; Hall et. al., 2002). It is primarily grown in drier regions of the world where it is one of the most droughtresistant food legumes (Dadson et. al., 2005). According to Martins et. al., (2003) Cowpeas grow best during summer, the base temperature for germination is $8.5^{\circ} \mathrm{C}$ and for leaf growth $20^{\circ} \mathrm{C}$. Cowpea is a heat-loving and drought-tolerant crop. The optimum temperature for growth and development is around $30{ }^{\circ} \mathrm{C}$. Many workers have reported that cowpea is drought-tolerant and show a great deal of drought avoidance under conditions of water deficit. Drought avoidance by cowpeas appears to be mainly due to several mechanisms for regulating rate of water uptake (Hall, 2004). Cowpeas utilize soil moisture efficiently and are more drought-tolerant than groundnuts, soya-beans and sunflowers.

It can adapt well to the sub-humid climate of Ethiopian western lowlands with high levels of germination and vigor. Biomass yields in DM bases averaged to 4.3 ton $\mathrm{h}^{-1}$ which can sustain more than 550 lactating Borana goats at their highest milk yield (Bilatu. A, and Ferede. A, 2012). It also plays an important nutritional role in the sub-Saharan areas because of the protein and vitamins of high quality contained in its grains and leaves (Fotso et. al., 1994).Because of its superior 
nutritional attributes, versatility, adaptability, and productivity, cowpea was chosen by the US National Aeronautical and Space Administration (NASA) as one of few crops worthy of study for cultivation in space stations (Ehlers and Hall, 1997).

Development of improved forages to improve livestock productivity is crucial. Livestock are an important part of the farming system of Kellem and West Wollega zone and one of the bottlenecks of livestock production is seasonality in quality and quantity of forage. Despite these positive attributes, livestock farmers in Kellem and West Wollega are mainly dependent on grazing lands and crop residues, and very little or no attention is given for improved forage species including legumes. Therefore, the study was undertaken the objective to identify and evaluate better adaptable, herbage and grain yield performance of some cowpea.

\section{MATERIALS AND MeTHODS}

\subsection{Description of the Study Area}

The study was conducted at Haro Sabu Agricultural Research Center (HSARC) during the main cropping season. The center is located in western Ethiopia in Oromia region at $550 \mathrm{~km}$ from Addis Ababa. It lies at latitude of $8^{\circ} 52^{\prime} 51^{\prime \prime} \mathrm{N}$ and longitude $35^{\circ} 13^{\prime} 18^{\prime \prime} \mathrm{E}$ and altitude of $1515 \mathrm{~m}$ above sea level. It has a warm humid climate with average minimum and maximum temperature of 14 and $30^{\circ} \mathrm{C}$, respectively. The area receives average annual rain fall of $1000 \mathrm{~mm}$ and its distribution pattern is uni-modal. The rain season covers from April to October. The soil type of the experimental site is reddish brown with sandy loam in texture, high organic matter content(7.4\%), medium carbon content $(5 \%)$, medium total nitrogen content $(0.43 \%)$, low available phosphorus content $(6.28 \mathrm{ppm})$, and exchangeable potassium content $(0.65 \%)$ and $\mathrm{pH}$ of 5.3 . The area is characterized by coffee based farming system and crop-livestock mixed farming system (HSARC, 2012).

\subsection{Experimental Design, Treatments and Layout}

The experiment was conducted using a Randomized Complete Block Design (RCBD) with 3 replications. A total of 5 treatments (Cowpea Ivu11421, Cowpea17216, Cowpea12688, Cowpea82d889, and CowpeaIt82d889) were used. Experimental unit comprised 6 rows of 2 meters length with row to row distance of $40 \mathrm{~cm}$ i.e. it was carried out on the plot size $3 \mathrm{~m} \times 3.2 \mathrm{~m}$ and distance of $1.5 \mathrm{~m}$ between replication.

Fertilizers was applied at a rate of $100 \mathrm{~kg} / \mathrm{ha}$ DAP during establishment for all experimental units and Weeding was done as early as possible to eliminate re-growth of undesirable plants and in order to promote fodder re-growth by increasing soil aeration will also be done. The plots will be kept weed free throughout growth period (Orodho, 2006).

\subsection{Yield Determination}

For the purpose of yield determination, the entire herbage from the net plot area $(1 \mathrm{~m} \mathrm{x} 1 \mathrm{~m})$ was cut close to the ground. The harvested green forage was weighed plot wise using hanging scale of $50 \mathrm{~kg}$ capacity and the total sample fresh yield (TSFW) in q ha-1 was estimated. Sub Samples of about 100 $\mathrm{gm}$ was taken from each plot and dried in oven at $60{ }^{\circ} \mathrm{C}$ to constant weight from which dry matter yield (DMY) was determined by dividing the oven-dried weight to its fresh weight expressed as percentage. The dry matter yield (DMY) in qha-1 was estimated by multiplying the green forage yield (qha-1) with that of the sample dry matter content divided by 100.

1. Fresh fodder yield (t ha-1): At $50 \%$ flowering stage, all treatments of each replications were harvested and weighed to get fresh fodder yield (FFY). The yields obtained were converted into $t$ ha-1.

2. Dry matter (\%): For dry matter determination, 100 gm of plant sample was weighed in each container and placed in an oven at $60{ }^{\circ} \mathrm{C}$ for $72 \mathrm{hrs}$ till constant weight was attained. Dry matter percentage was calculated by the following formula.

$$
\operatorname{Dry} \operatorname{Matter}(\%)=\frac{\text { Wt. of oven dry sample }}{\text { Wt. of sample before drying }}
$$

3.Dry matter yield (t ha-1): Dry fodder yield (DMY) was calculated by applying this formula.

$$
\text { FFY x DM (\%) }
$$

DMY $(\mathrm{t}$ ha-1) $=$ 
Adaptation Trail of Improved legume cowpea, (Vigenia Angulucata) at Haro Sabu, Kelem Wollega Zone, Oromia, Ethiopia

\subsection{Data Collected}

Data recorded were establishment data (four and eight weeks germination,) disease recorded ,days of $50 \%$ flowering, grain yield and biomass yield such as total fresh weight, sample fresh weight, dry matter(DM) yield.

\subsection{Statistical Data Analysis}

The data were subjected to statistical analysis using SAS 9.1 computer software. Treatment means were compared using Least Significant Difference (LSD) test at 5\% level of probability (Steel \& Torrie, 1980).

\section{RESULTS AND DISCUSSIONS}

\subsection{Plant Growth Performance}

Plant number, percent of plant coverage, days at 50\% flowering, disease resistance, herbage yield of cowpea accessions during adaptation period in 2012/13 cropping season was presented and were significant between treatments at $(\mathrm{p}<0.05)$ in table 1 . Herbage dry matter yield and sample dry matter Plant population in a given area is an important factor to determine forage and grain yield particularly for an annual forage like cowpea. The plant number at four week of cowpea accessions during adaptation period in 2010/11 cropping season 21.7, 19.7, 19.0, 18.0, 15.3 were recorded from accessions Cowpea12688, Cowpea82d889, Cowpea17216, CowpeaIt82d889, Cowpea Ivu11421 respectively. Mean plant number at four week was $18.73 / \mathrm{m}^{2}$. Plant numbers at eight weeks were the same as the four weeks and also their means were the same. Cowpea12688 accesion has more planted at four \& eight weeks compared to the rest. The plant soil coverage at four weeks 25.7, 23.3, 21.0, 20.7, 18.7 percents was covered by cowpea a accession of CowpeaIt82d889, Cowpea12688, Cowpea82d889, Cowpea17216, and Cowpea Ivu11421 respectively. The Mean of plant soil cover at four weeks was 21.87 percent. The highest eight weeks plant cover 69.7, 65.0, 64.7, 45.0, 41.3 percent were obtained from cowpea accessions of CowpeaIt82d889, Cowpea17216, Cowpea12688, Cowpea82d889 and Cowpea Ivu11421 respectively. Mean of plant cover at Eight week was 57.13 percent. At both (Four and Eight) weeks CowpeaIt82d889 accession has highest percent of plant coverage compared to the rest. Cowpea was annual legume improved forage crop can flower to set seed. From five different adapted cowpea accessions, the accessions achieved 50\% flowering on average in 40.25 days after planting. Cowpea17216 accession has shortest days (33 days) of 50\% flowering whereas Cowpea82d889 has the longest days (47 days) of 50\% flowering to set seed when compared to rest accessions from the tested.

\subsection{Fresh and Dry Matter (Biomass) Yield}

The herbage yield of cowpea accessions are presented in table 1. The differences among cowpea accessions, fresh weight was found statistically significant differences $(\mathrm{p}<0.05)$. During the period of experiment carried out, from net area $1 \mathrm{mx} 1 \mathrm{~m}, 57.91,43.3$ and $34 \mathrm{t} \mathrm{ha}^{-1}$ fresh weights were obtained from CowpeaIt82d889, Cowpea82d889 and Cowpea17216 respectively. This shows that CowpeaIt82d889 accession was high fresh forage yielder $\left(57.91 \mathrm{t} \mathrm{ha}^{-1}\right)$ compared to the rest accessions. The mean fresh weight yield was $38.45 \mathrm{tha}^{-1}$

Table 1: Mean value separation of different parameters Adapted forage legume Cowpea (Vigenia angulucata) in 2012/13 at HSARC

\begin{tabular}{|c|c|c|c|c|c|c|c|c|c|c|c|}
\hline Accession & FWPN & FWSC & EWPN & EWSC & $\begin{array}{l}\mathrm{D} 50 \% \\
\mathrm{~F} \text { (day) } \\
\end{array}$ & \begin{tabular}{|l} 
DIN \\
$\%$
\end{tabular} & $\begin{array}{l}\text { TFW t } \\
\text { ha }^{-1}\end{array}$ & $\begin{array}{l}\text { SFW } \\
\text { gm/plot }\end{array}$ & $\begin{array}{l}\text { SDWT } \\
\mathrm{gm} / \text { plot }\end{array}$ & $\begin{array}{l}\text { DMY } \\
\mathrm{ha}^{-1}\end{array}$ & $\begin{array}{ll}\begin{array}{l}\text { SDY } \\
\mathrm{ha}^{-1}\end{array} \\
\end{array}$ \\
\hline Cowpea12688 & $21.7^{\mathrm{a}}$ & $23.3^{\mathrm{b}}$ & $21.6^{\mathrm{a}}$ & $64.7^{b}$ & $39^{\mathrm{c}}$ & $1.0^{\mathrm{a}}$ & $29.75^{\mathrm{c}}$ & $100^{\mathrm{a}}$ & $19.043^{\mathrm{a}}$ & $5.6^{\mathrm{bc}}$ & 8.57 \\
\hline \begin{tabular}{|l} 
Cowpea82d889 \\
\end{tabular} & $19.7^{\mathrm{b}}$ & $21.0^{\mathrm{c}}$ & $19.7^{\mathrm{b}}$ & $45.0^{\mathrm{c}}$ & $47^{\mathrm{a}}$ & $0.5^{\mathrm{b}}$ & $43.31^{b}$ & $100^{\mathrm{a}}$ & $19.210^{\mathrm{a}}$ & $8.4^{\mathrm{ab}}$ & 7.93 \\
\hline Cowpea17216 & $19.0^{\mathrm{bc}}$ & $20.7^{\mathrm{cd}}$ & $19.0^{\mathrm{bc}}$ & $65.0^{b}$ & $33^{\mathrm{e}}$ & $0.5^{\mathrm{b}}$ & $34.02^{\mathrm{c}}$ & $100^{\mathrm{a}}$ & $18.233^{\mathrm{a}}$ & $4.5^{\mathrm{c}}$ & 15.42 \\
\hline CowpeaIt82d889 & $18.0^{\mathrm{c}}$ & $25.7^{\mathrm{a}}$ & $18.0^{c}$ & $69.7^{\mathrm{a}}$ & $45^{\mathrm{b}}$ & $0.5^{\mathrm{b}}$ & $57.91^{\mathrm{a}}$ & $100^{\mathrm{a}}$ & $17.773^{\mathrm{a}}$ & $10.4^{\mathrm{a}}$ & 21.45 \\
\hline Cowpea Ivu11421 & $15.3^{\mathrm{c}}$ & $18.7^{\mathrm{c}}$ & $15.3^{\mathrm{d}}$ & $41.3^{\mathrm{d}}$ & $37^{\mathrm{d}}$ & $0.5^{\mathrm{b}}$ & $27.29^{c}$ & $100^{\mathrm{a}}$ & $17.133^{\mathrm{a}}$ & $4.6^{\mathrm{c}}$ & 9.38 \\
\hline Mean & 18.73 & 21.87 & 18.73 & 57.13 & 40.25 & 0.6 & 38.45 & 100 & 18.3 & 6.7 & 12.55 \\
\hline LSD & 1.309 & 2.20 & 1.31 & 2.25 & 0 & 0 & 8.97 .4 & 0 & 3.02 & 3.12 & 18.57 \\
\hline $\mathrm{CV}(\%)$ & 3.7 & 5.35 & 3.71 & 2.1 & 0 & 0 & 12.4 & 0 & 8.72 & 24.68 & 73.54 \\
\hline
\end{tabular}

$F W P N=$ Four week plant number, FWSC $=$ Four week soil cover in $\%$, EWPN =Eight week plant number $E W S C=$ Eight week Soil cover in $\%, D 50 \% F=$ Days of $50 \%$ flowering, DIN= Disease incidence in $\%, \quad S D Y=$ Seed yield gm/plot TSFW= Total sample fresh weight, SFW= Sample fresh weight, SDWT= Sample dry weight, DMY= Dry matter yield 
Dry matter herbage yield was also significantly different between treatments at $(\mathrm{p}<0.05)$. The highest dry matter yield of $10.4,8.4,5.6 \mathrm{t} \mathrm{ha}^{-1}$ was obtained from a CowpeaIt82d889, Cowpea82d889 and Cowpea12688 respectively. The dry matter mean yield obtained was $6.7 \mathrm{t} \mathrm{ha}^{-1}$ ranged from $4.5 \mathrm{t}$ ha-1 for Cowpea17216 to $10.4 \mathrm{t}$ ha-1 for CowpeaIt82d889. Though the yield obtained was significantly higher than the studies reported on the dry matter yield of cowpea, $4.28 \mathrm{t}$ ha- 1 is recorded in Northwest lowlands of Ethiopia (Bilatu. A, Binyam. K, Solomon. Z, Eskinder. A and Ferede .A, 2012) which is comparable to the current study. Also Anele et al., (2011a) also reported significant $(\mathrm{P}<0.05)$ differences in herbage DM yield between commercial and improved cowpea varietal groups. The mean values for herbage DMY recorded in one of the accession (CowpeaIt82d889) are higher than values reported for three commercial $(6.46 \mathrm{t} / \mathrm{ha})$ and three improved (8.76 t/ha) groups of cowpea elsewhere (Anele et al., 2011b). On the other hand, the herbage DMY for Cowpea82d889 (8.4 t/ha) is comparable with a reported mean value of 8.76 t/ha reported for three improved cowpea cultivars grown in Southwest Nigeria (Anele et al.,2011b). From five adapted cowpea accessions at Haro sabu agro ecologies, the CowpeaIt82d889 produced the highest fresh weight and dry matter yield followed by Cowpea82d889 accession.

\subsection{Grain Yield}

The average grain/seed yield for the five cowpea accessions was $12.55 \mathrm{q} / \mathrm{ha}$ and this value was not significantly varied among varieties (Table 1). But numerically high grain yield was recorded form CowpeaIt82d889 accession with 21.45 q ha-1 while the yield of Cowpea82d889 was lower than all the accessions with7.93 q ha-1. About $20 \mathrm{q}$ ha- 1 cowpea grain is reported under research environment (Takim and Uddin, 2010). Location and environment wise, high yield was recorded (21.45 q ha-1) in study area. Though the grain yield obtained was significantly higher than the studies reported on the grain yield of cowpea, $20 \mathrm{q}$ ha-1 is reported under research environment (Takim and Uddin, 2010) which is comparable to the current study.

\subsection{Disease Resistance}

Fungal, bacterial and viral diseases affect different parts of cowpea at different stages of growth. Insect pests are also other constraining factors in cowpea production that severely attack the crop at every stage of its growth and make the use of tolerant varieties and insecticide sprays mandatory (Dugje et al., 2009). In this study, however, there was significant disease recorded (score of 0.6) in these accessions at pre-harvesting stage except rare and random attack at early emergence which mostly pronounced on undersurface of young leaves. From the result (table 1), Indicated that from fives cowpea adapted, Cowpea12688 accession was affected by disease compared to the rest accessions.

Table 2. Analysis of variance of Adapted forage legume Cowpea (Vigenia angulucata) in 2012/13 at HSARC

\begin{tabular}{|l|l|l|l|l|l|}
\hline Traits & Rep.MS(df=2) & TrtMS(df=17) & MSE(df=6) & Mean & CV (\%) \\
\hline FWPN & $0.067 \mathrm{~ns}$ & $16.23^{*}$ & 0.483 & 18.73 & 3.7 \\
\hline FWPC & $1.867 \mathrm{~ns}$ & $21.767^{*}$ & 1.367 & 21.78 & 5.73 \\
\hline EWPN & $0.067 \mathrm{~ns}$ & $16.23^{*}$ & 0.483 & 18.73 & 3.71 \\
\hline EWPC & $3.267 \mathrm{~ns}$ & $504.43^{*}$ & 1.43 & 57.13 & 2.1 \\
\hline DIN & 0 & $0.15^{*}$ & 0 & 0 & 0 \\
\hline D50F & 0 & $99.6^{*}$ & 0 & 40.2 & 0 \\
\hline TFW & $1522.27 \mathrm{~ns}$ & $4666910.01^{*}$ & 227148.69 & 3845.9 & 12.4 \\
\hline SFW & 0 & 0 & 0 & 100 & 0 \\
\hline SDW & $2.473 \mathrm{~ns}$ & 2.266 & 2.5414 & 18.3 & 8.72 \\
\hline DMY & $897430.9 \mathrm{~ns}$ & $19262583.25^{*}$ & 2736278.5 & 6700.780 & 24.68 \\
\hline SDY & $12830.024 \mathrm{~ns}$ & $7584.423 \mathrm{~ns}$ & 8968.771 & 120.50 & 73.54 \\
\hline
\end{tabular}

$F W P N=$ Four week plant number, FWSC $=$ Four week soil cover in $\%$, EWPN =Eight week plant number $E W S C=$ Eight week Soil cover in $\%, D 50 \% F=$ Days of $50 \%$ flowering, DIN= Disease incidence in \%, SDY= Seed yield gm/plot TSFW= Total sample fresh weight, SFW= Sample fresh weight, SDWT= Sample dry weight, DMY=Dry matter yield, $n s=$ non significance, $*=$ significance difference

\section{CONCLUSION AND RECOMMENDATION}

From the present study it can be concluded that the tested cowpea accessions can adapt well to the lowland climates of Kellem and west Wollega zones of Oromia regional state. From five adapted cowpea accessions CowpeaIt82d889, Cowpea82d889 and Cowpea17216 are well adapted herbage dry 
matter and grain yielder respectively and they are suitable for use as animal feeds under the study area. As a result, to recommend that these two accessions were suitable at this area and better to popularize and demonstrate this technology reaches farmers and animal producers better to use for their livestock mix with poor quality (low protein content) as feed resources to enhance animal products.

\section{ACKNOWLEDGEMENT}

We express our greatest gratitude to Oromia Agricultural Research Institute for their provided the finance and necessary facilitation the work of "Adaptation trail of improved legume cowpea, (Vigenia angulucata) at Haro Sabu, kelem wollega zone, Oromia, Ethiopia".

\section{REFERENCES}

[1] Alemayehu M (2002). Forage productionin Ethiopia acase study with implications for livestock production. Ethiop. Soc. Anim. Prod.(ESAP). Addis Ababa, Ethiopia

[2] Anele UY, Sudekum KH, Arigbede OM, Welp G, Adebayo OO, Jimoh AO and Olubunmi VO (2011b). Agronomic performance and nutritive quality of some commercial and improved dual-purpose cowpea (Vigna unguiculataL. Walp) varieties on marginal land in Southwest Nigeria. Grassland Sci., 57: 211-218.

[3] Bilatu. A*, Binyam. K, Solomon. Z, Eskinder. A and Ferede .A, 2012. Animal feed potential and adaptability of some cowpea (Vigna unguiculata) varieties in North West lowlands of

[4] Ethiopia. Wudpecker Journal of Agricultural Research Vol. 1(11), pp. 478 - 483.

[5] Dadson R.B., Hashem F.M., Javaid I., Allen A.L., Devine T.E., 2005. Effect of water stress on yield of cowpea (Vignaunguiculata L. Walp.) genotypes in the Delmarva region of the United States. Journal of Agronomy and Crop Science, 191:210-217.

[6] Dugje IY, Omoigui LO, Ekeleme F, Kamara AY, Ajeigbe H (2009).Farmers' Guide to Cowpea Production in West Africa. International Institute of Tropical Agriculture (IITA), Ibadan, Nigeria.

[7] Ehlers J.D. and Hall A.E. Cowpea [Vignaunguiculata (L.) Walp.]. 1997. Field Crops Research. 53,187-204

[8] Hall A.E., Ismail A.M., Ehlers J.D., Marfo K.O., Cisse N., Thiaw S., Close T.J., 2002. Breeding cowpeas for tolerance to temperature extremes and adaptation to drought. Challenges and Opportunities for Enhancing Sustainable Cowpea Production, International Institute of Tropical Agriculture, Ibadan, Nigeria, pp. 14-21

[9] Hall A.E., 2004. Breeding for adaptation to drought and heat in cowpea. European Journal of Agronomy, 21: 447-454.

[10] Haro Sabu ARC, 2012. Annual report of Haro Sabu Agricultural Research center, Haro Sabu.

[11] Martins L.M.V., Xavier G.R., Rangel F.W., Ribeiro J.R.A., Neves M.C.P., Morgado L. B. and Rumjanek N.G., 2003. Contribution of biological fixation to cowpea: A strategy for improving seed yield in the semi-arid region of Brazil. Biology and Fertility of Soils, 38: 333-339.

[12] SAS, 1998.SAS/STAT guide to personal computers - Version 7. (Statistical Analysis System Institute Inc.: Cary, NC).

[13] Sere, C, Ayantunde, A, Duncan, A, Freeman, A, Herrero, M, Tarawali, S and Wright, I. 2008. Livestock production and poverty alleviation challenges and opportunities in arid and semi- arid tropical rangeland based systems. In: the proceedings of multi-functional grasslands in a changing world. XXI International Grassland Congress and VII International Rangeland Congress, China.19-29 pp.

[14] Steel, R.G.D. and Torrie, J.H. 1980. Principles and procedures of statistics: a biometrical approach. 2 Ed. New York, USA.

[15] Takim FO, Uddin RO (2010). Effect of weed removal on insect populations and yield of Cowpea [Vignaunguiculata (L) Walp]. Aust. J. Agric. Eng., 1(5):194-199. 